\title{
Ethno-specific preferences of cigarette smoking and smoking initiation among Canadian immigrants - a multi-level analysis
}

This article was published in the following Dove Press journal:

Patient Preference and Adherence

\section{Yelena Bird \\ Killian Forbeteh \\ Chijioke Nwankwo \\ John Moraros}

School of Public Health, University of Saskatchewan, Saskatoon, Canada

Correspondence: John Moraros School of Public Health, University of Saskatchewan, 104 Clinic Place, E-Wing Health Sciences, Room 3320, Saskatoon, SK S7N 2Z4, Canada

$\mathrm{Tel}+\mathrm{I} 306$ 36| 4633

Email john.moraros@usask.ca
Background: Cigarette smoking is the leading cause of preventable morbidity and mortality worldwide. Over the last decade, increased immigration has significantly shifted Canada's demographic profile. According to a 2011 National Household Survey, approximately $20.6 \%$ of the Canadian population was immigrants, the highest among the G8 countries. It is estimated that by 2031, one-in-three Canadian's will be an immigrant. This study examined the ethno-specific preference of cigarette smoking and smoking initiation among Canadian immigrants.

Methods: This study used data from the 2013 to 2014 combined cycles of the Canadian Community Health Survey. This was a nationally generalizable, telephone-based survey that included a total of 130,000 respondents, aged 12 years or older. Ethnic differences in the preference of cigarette use among Canadian immigrant groups were determined. A three-level mixed effects logistic regression model was used to estimate the effect of ethnicity on the likelihood of smoking initiation after migration to Canada.

Results: In our study, $82 \%$ of respondents were native-born Canadians (one group), while the rest were immigrants ( statistically significant differences in the number of cigarettes smoked daily ( $P=0.0001)$, age of smoking onset $(P=0.0001)$, and smoking initiation $(P=0.0001)$ between Canadian-born and immigrant participants. Immigrant smokers in Canada were significantly more likely to be younger, single, Caucasian, females with high income and post-secondary education ( $P=0.0001)$.

Conclusion: The results of our study suggest that Caucasian female immigrants in Canada initiated smoking at a younger age and smoked more cigarettes than any other immigrant group or native-born Canadians. This is a particularly interesting finding as Caucasian female immigrants may not be considered a vulnerable or at-risk population. To be effective, tobacco strategies specifically tailored for this overlooked population would require increased awareness, culturally appropriate initiatives, and gender-specific interventions.

Keywords: cigarette smoking, initiation, ethnicity, immigrants, Canada

\section{Introduction}

Cigarette smoking is the leading cause of morbidity and mortality in ethnic populations across North America, including Canada. ${ }^{1}$ It is estimated that every year, approximately 40,000 Canadians ${ }^{2}$ die due to smoking-related diseases, leading to 16 billion dollar in indirect and direct economic costs. ${ }^{3}$ In 2014, approximately 5.4 million Canadians were either daily or occasional smokers. ${ }^{4}$ Even though a large number of Canadians smoke, an increasing number of immigrants also significantly contribute to the country's smoking profile., ${ }^{5,6}$ The projected growth in Canada's immigrant population 
necessitates that more research focuses on understanding the smoking behaviors among immigrants.

Over the last decade, increased immigration has shifted Canada's demographic profile. According to a 2011 National Household Survey, approximately $20.6 \%$ of the Canadian population was immigrants, the highest among the G8 countries. ${ }^{7}$ It is estimated that by 2031 , one-in-three Canadian's will be an immigrant. ${ }^{8}$ Smoking is reported to be one of the leading sources of health disparity among ethnic minorities. ${ }^{9}$ Many studies have explored smoking in multiethnic populations. ${ }^{1,10-12}$ Findings from these studies reveal a considerable variability in smoking behaviour between different immigrant ethnic groups and their host countries. ${ }^{13}$

Although smoking is an individual behaviour, a number of multi-level factors are known to predispose, reinforce, and enable this behaviour. Income, religion, education, psychological stress, targeted advertising, price and availability of tobacco products, peer influence, parenting, and ethnicity are among the factors that have been identified as likely contributors to racial/ethnic differences in smoking. ${ }^{12-14}$ Studies have shown that the level of smoking between new immigrants and native-born citizens tend to become similar as immigrants spend more time in their host country. ${ }^{15-17}$

Smoking behaviour can be conditioned by culture and may vary with ethnicity. ${ }^{11,15-17}$ Some individuals migrate to countries from cultures where smoking may be considered a common social practice, while for others it may be unacceptable to smoke. ${ }^{15-18}$ As Canada's immigration population is rapidly growing, health research among its ethnic minority populations has become increasingly important. To date, very little is known about the smoking behaviors of immigrants in Canada. This study examined the ethno-specific preference of cigarette smoking and smoking initiation among Canadian immigrants.

\section{Methods}

\section{Data and sample}

This study used data from the combined cycles of the Canadian Community Health Survey (CCHS), 2013-2014. This was a nationally generalizable, telephone-based survey that included a total of 130,000 respondents, aged 12 years or older, living in ten provinces and three territories, with high participation rates $(92 \%-97 \%)$. Excluded from the survey were Aboriginal settlements in the provinces, fulltime members of the Canadian Forces, institutionalized populations and people living in certain Quebec health regions (Région du Nunavik and Région des Terres-Criesde-la-Baie-James). ${ }^{19}$
The data were collected by Statistics Canada. The investigators acquired access to the confidential Master Data File for the 2013/14 CCHS. The CCHS contains relevant questions on smoking as well as representative data on various healthrelated behaviors and sociodemographic characteristics. Appropriate weighting was applied to the data. Bootstrap procedures were employed to calculate the CIs and coefficients of variation for the measures of effect obtained to account for the survey design. A significance level of $P<0.05$ was applied in all cases.

\section{Measures}

All measures were obtained at the individual participant level. The smoking behaviors were categorized and defined as follows: daily smoker (smoke daily at present time and has smoked more than 100 cigarettes in lifetime); occasional smoker (never a daily smoker and has smoked less than 100 cigarettes in lifetime); and never smoker (never smoked a whole cigarette and has never smoked 100 cigarettes in lifetime). To assess the smoking preferences among Canadian immigrants, the following outcome measures were used: number of cigarettes smoked daily; the age of smoking onset; smoking habits; and smoking initiation. Smoking initiation was obtained by subtracting the age of migration from the age at which a respondent first smoked a whole cigarette. A positive value for the smoking initiation variable suggested the individual started smoking after migration, while negative values were indicative of smoking initiation prior to migration.

The primary variables of interest were the ethnicity and immigrant status of the respondents. Respondents were identified as belonging to one of the following ethnic/racial categories: Caucasian, Asian, Black, Latino, Arab, or Others (if not identifying with any of the listed categories). Other covariates of interest were also taken into account in our analyses and included marital status, self-perceived health, self-perceived mental health, self-perceived life stress, selfperceived work stress, province of residence, health region of residence, sex, frequency of alcohol intake, highest level of education, and total household income.

\section{Data analyses}

\section{Smoking preferences}

To determine the difference in the smoking preferences among the various ethnic immigrant groups in Canada, a one-way ANOVA was used. It assessed the differences in the mean number of cigarettes smoked daily and in the mean age of smoking onset. The one-way ANOVA F-test for 
independent samples was used if the data were normally distributed and had equal variances. In the event that either of the aforementioned conditions were not met, the Kruskal-Wallis one-way ANOVA was used instead. To assess the ethnic differences in smoking habits, a chi-squared test of independence was used to test for the equality of proportions.

\section{Smoking initiation}

To account for the hierarchical structure of our data, a threelevel mixed effects logistic regression model was used to estimate the effect of ethnicity and immigrant status (adjusted for other covariates) on the likelihood of smoking initiation after migration to Canada.

\section{Model building}

An unconditional analysis was carried out for each of the variables of interest with the outcome using a cut off value of $P=0.20$. Any variable whose independent relationship with the outcome resulted in a $P>0.20$ was removed from the model. All explanatory variables that passed the unconditional analyses were then assessed for evidence of multicollinearity. A backward model building approach was used to obtain the final (adjusted) model $(P<0.05) .{ }^{20}$ Confounding effects were assessed by observing the proportionate change in the values of the $\beta$-coefficients for the primary predictor with and without the variable of interest in the model. A proportionate change of $P \geq 0.2$ was deemed to show confounding. ${ }^{21}$

Effect modification was determined by assessing for statistical significance of the $\beta$-coefficient of a cross-product term generated by multiplying the primary predictor and the variable of interest. ${ }^{22}$ The effect estimates were exponentiated to obtain easily interpretable odds ratios and the random effect was estimated by calculating the intraclass correlation using the latent variable approach. ${ }^{22,23}$ A receiver operating curve was used to ascertain the fitness of the model. All analyses were carried out using Stata IC, version 13.

\section{Results \\ Sociodemographic characteristics}

In our study, $82 \%$ of respondents were native-born Canadians (one group), while the rest of respondents were immigrants ( six groups=18\%). Of the immigrants, 9.7\% were Caucasian, 5\% were Asian, and 1.2\% were Latinos, while Blacks, Arabs and Other ethnicities made up the rest of the sample $(0.9 \%$, $0.8 \%$, and $0.4 \%$ respectively). The majority of the respondents were males (54.7\%), were married or had common-law partners $(62.8 \%)$, with a post-secondary certificate $(57.5 \%)$, and earned an income between $\$ 38,500$ and $\$ 77,000$ (CAD).
Over half of the respondents $(56.1 \%)$ believed they were in excellent or very good health but as many as $66.3 \%$ reported feeling some amount of stress (Table 1).

\section{Smoking preferences}

To determine if the number of cigarettes smoked daily differed between the various ethnic immigrant groups and the nativeborn Canadians, a Kruskal-Wallis H test was conducted. The test showed that there was a statistically significant difference in the number of cigarettes smoked daily $\left[\chi^{2}(6)=246.302\right.$, $P=0.0001]$, smoking onset $\left[\chi^{2}(6)=1,347.799, P=0.0001\right]$ and daily or occasional smokers $\left[\chi^{2}(12)=480.8543, P<0.0001\right]$ between the various ethnic groups and the native-born Canadians (Table 2).

\section{Multi-level regression model}

In our multi-level regression model analysis, the age of respondents played a significant role in determining if an immigrant was to start smoking post-arrival to Canada. Respondents who were 18 years old or younger were more likely to start smoking post-migration to Canada, when compared to older age groups $(P=0.0001)$. Additionally, our study shows that respondents who were single, Caucasian, females, with high income and some post-secondary education were more likely to start smoking post-migration to Canada $(P=0.0001)$. Other covariates that were significant predictors of smoking initiation post-migration to Canada included perceived self-health and perceived life stress (Table 3 ).

\section{Marginal effects}

Our study also examined the effect of ethnicity on the likelihood of smoking initiation post-migration to Canada (Table 4). Among non-smoking immigrants, Arabs had the greatest likelihood to initiate smoking post-migration to Canada (odds ratio $[\mathrm{OR}]=2.4$ ). Among the respondents identified as occasional smokers, only Asian immigrants showed a statistically significant odds ratio of smoking initiation post-migration to Canada ( $\mathrm{OR}=1.4)$. Among daily smokers, Caucasian, Black, and Other immigrants were all more likely to have started smoking post-migration $(\mathrm{OR}=1.3,1.2$, and 1.1, respectively), while Asian and Latino immigrants were more likely to have initiated smoking prior to migration to Canada ( $\mathrm{OR}=0.6$ and 0.3 , respectively) (Table 4).

\section{Discussion}

Canada is increasingly becoming a culturally diverse country. Immigrants are gradually representing a more sizeable share of the total Canadian population. Therefore, it is important 
Table I Sociodemographic characteristics

\begin{tabular}{|c|c|c|}
\hline Variables & Variable category & Percentage (\%) \\
\hline \multirow{7}{*}{$\begin{array}{l}\text { Ethnicity } \\
(N=\mid 5,98 I, 76 I)\end{array}$} & Native-born Canadian & 82.0 \\
\hline & Caucasian & 9.7 \\
\hline & Asian & 5.0 \\
\hline & Black & 0.9 \\
\hline & Latino & 1.2 \\
\hline & Arab & 0.8 \\
\hline & Other & 0.4 \\
\hline \multirow{5}{*}{$\begin{array}{l}\text { Age category } \\
(\mathrm{N}=|5,996,9| 7)\end{array}$} & Less than 18 years & 1.4 \\
\hline & $18-25$ years & 9.8 \\
\hline & $26-44$ years & 30.7 \\
\hline & $45-65$ years & 38.6 \\
\hline & Greater than 65 years & 19.5 \\
\hline \multirow{4}{*}{$\begin{array}{l}\text { Income } \\
(\mathrm{N}=15,996,894)\end{array}$} & Less than 38,500 & 24.9 \\
\hline & $38,500-77,000$ & 32.8 \\
\hline & $77,001-118,000$ & 20.8 \\
\hline & Greater than II 8,000 & 21.5 \\
\hline \multirow{3}{*}{$\begin{array}{l}\text { Marital status } \\
(\mathrm{N}=15,959,850)\end{array}$} & Single & 22.8 \\
\hline & Married/common-law & 62.8 \\
\hline & Separated/widowed/divorced & 14.4 \\
\hline \multirow{5}{*}{$\begin{array}{l}\text { Perceived self-health } \\
(\mathrm{N}=\mid 5,980,455)\end{array}$} & Excellent & 18.1 \\
\hline & Very good & 38.0 \\
\hline & Good & 30.6 \\
\hline & Fair & 9.8 \\
\hline & Poor & 3.5 \\
\hline \multirow{5}{*}{$\begin{array}{l}\text { Perceived life stress } \\
(\mathrm{N}=|5,956,3| 3)\end{array}$} & Not at all & 11.3 \\
\hline & Not very & 22.4 \\
\hline & A bit & 42.0 \\
\hline & Quite a bit & 20.5 \\
\hline & Extremely & 3.8 \\
\hline \multirow{2}{*}{$\begin{array}{l}\text { Sex } \\
(N=15,996,9 \mid 7)\end{array}$} & Male & 54.7 \\
\hline & Female & 45.3 \\
\hline \multirow{4}{*}{$\begin{array}{l}\text { Education } \\
(\mathrm{N}=15,744,206)\end{array}$} & Less than secondary school graduate & 15.8 \\
\hline & Secondary school graduate & 21.4 \\
\hline & Some post-secondary education & 5.3 \\
\hline & Post-secondary certification & 57.5 \\
\hline \multirow{4}{*}{$\begin{array}{l}\text { Alcohol frequency } \\
(\mathrm{N}=13,697,969)\end{array}$} & Less than once a month & 18.2 \\
\hline & More than once a month but not weekly & 22.1 \\
\hline & More than once a week but not daily & 49.0 \\
\hline & Daily & 10.7 \\
\hline \multirow{3}{*}{$\begin{array}{l}\text { Type of smoker } \\
(N=15,994,342)\end{array}$} & Daily ${ }^{\mathrm{a}}$ & 24.9 \\
\hline & Occasionally $^{b}$ & 8.4 \\
\hline & Never ${ }^{c}$ & 66.7 \\
\hline
\end{tabular}

Notes: ${ }^{a}$ Daily smoker, smokes daily at present time and has smoked more than 100 cigarettes in lifetime. ${ }^{b}$ Occasional smoker, never a daily smoker and has smoked less than 100 cigarettes in lifetime. 'Never smoker, never smoked a whole cigarette and has never smoked 100 cigarettes in lifetime.

to examine and conduct research on the effect of immigrant status and ethnic variability as they relate to a number of important health issues, including smoking. Many studies on smoking among multi-ethnic populations have revealed significant variability in smoking preferences between different ethnic immigrant groups and the host population. ${ }^{13}$

Our study found significant variations in the smoking preferences, smoking initiation, and sociodemographic 
Table 2 Smoking preferences

\begin{tabular}{|l|l|l|l|}
\hline $\begin{array}{l}\text { Participants' immigrant } \\
\text { and ethnic status }\end{array}$ & $\begin{array}{l}\text { Median number of } \\
\text { cigarettes smoked daily (N) }\end{array}$ & $\begin{array}{l}\text { Median age of } \\
\text { smoking onset (years) }\end{array}$ & $\begin{array}{l}\text { Proportion of daily or } \\
\text { occasional smokers (\%) }\end{array}$ \\
\hline Native-born Canadians & 13 & 15 & 34.3 \\
\hline Caucasian immigrants & 15 & 16 & 26.0 \\
\hline Asian immigrants & 7 & 18 & 33.3 \\
\hline Black immigrants & 6 & 18 & 26.8 \\
\hline Latino immigrants & 8 & 17 & 23.4 \\
\hline Arab immigrants & 10 & 18 & 45.5 \\
\hline Other immigrants & 10 & 18 & 35.0 \\
\hline
\end{tabular}

characteristics among ethnic immigrant groups and nativeborn Canadians. Specifically, Caucasian immigrants smoked 15 cigarettes daily, which was a higher average than any other immigrant group but close to the 13 cigarettes smoked a day by native-born Canadians. This finding is supported by Asbridge et al, who found smoking to be a highly acceptable behaviour among people of European ancestry. ${ }^{15}$ It is possible this socio-cultural acceptability of smoking follows European immigrants to Canada. Therefore, the close resemblance in the median number of cigarettes smoked daily

Table 3 Multi-level regression model

\begin{tabular}{|c|c|c|c|c|}
\hline Variables & OR & LL $95 \% \mathrm{CI}$ & UL $95 \% \mathrm{Cl}$ & $P$-value \\
\hline & 0.04 & 0.02 & 0.06 & $<0.0001$ \\
\hline Ethnicity & & & & $<0.0001$ \\
\hline \multirow{6}{*}{$\begin{array}{l}\text { Caucasian immigrants } \\
\text { Asian immigrants } \\
\text { Black immigrants } \\
\text { Latino immigrants } \\
\text { Arab immigrants } \\
\text { Other immigrants }\end{array}$} & Ref & & & \\
\hline & 0.40 & 0.32 & 0.50 & \\
\hline & 0.39 & 0.25 & 0.60 & \\
\hline & 0.35 & 0.24 & 0.51 & \\
\hline & 0.79 & 0.44 & 1.41 & \\
\hline & 0.49 & 0.29 & 0.82 & \\
\hline Age category & & & & $<0.0001$ \\
\hline \multirow{5}{*}{$\begin{array}{l}\text { Older than } 65 \text { years } \\
\text { Younger than } 18 \text { years } \\
18-25 \text { years } \\
26-44 \text { years } \\
45-65 \text { years }\end{array}$} & Ref & & & \\
\hline & 40.08 & 5.23 & 307.27 & \\
\hline & 3.54 & 2.52 & 4.95 & \\
\hline & 1.70 & 1.41 & 2.04 & \\
\hline & 1.76 & 1.52 & 2.04 & \\
\hline Income & & & & $<0.0001$ \\
\hline \multirow{4}{*}{$\begin{array}{l}\text { Less than } \$ 38,500 \\
\$ 38,500-\$ 77,000 \\
\$ 77,00-\$ 118,000 \\
\text { Older than } \$ 118,000\end{array}$} & Ref & & & \\
\hline & 1.48 & 1.28 & 1.71 & \\
\hline & 1.85 & 1.54 & 2.22 & \\
\hline & 2.33 & 1.91 & 2.84 & \\
\hline Marital status & & & & $<0.0001$ \\
\hline \multirow{3}{*}{$\begin{array}{l}\text { Married/common-law } \\
\text { Single } \\
\text { Separated/widowed/divorced }\end{array}$} & Ref & & & \\
\hline & 2.94 & 2.45 & 3.53 & \\
\hline & 1.44 & 1.24 & 1.67 & \\
\hline Perceived self-health & & & & 0.0348 \\
\hline \multirow{5}{*}{$\begin{array}{l}\text { Poor } \\
\text { Excellent } \\
\text { Very good } \\
\text { Good } \\
\text { Fair }\end{array}$} & Ref & & & \\
\hline & 1.61 & 1.13 & 2.30 & \\
\hline & 1.67 & 1.19 & 2.36 & \\
\hline & 1.52 & 1.08 & 2.14 & \\
\hline & 1.40 & 0.97 & 2.03 & \\
\hline
\end{tabular}

(Continued) 
Table 3 (Continued)

\begin{tabular}{|c|c|c|c|c|}
\hline Variables & OR & LL 95\% Cl & UL 95\% CI & $P$-value \\
\hline Perceived life stress & & & & 0.0070 \\
\hline \multirow{5}{*}{$\begin{array}{l}\text { Not at all } \\
\text { Not very } \\
\text { A bit } \\
\text { Quite a bit } \\
\text { Extremely }\end{array}$} & Ref & & & \\
\hline & 1.36 & 1.13 & 1.62 & \\
\hline & 1.21 & 1.02 & 1.44 & \\
\hline & 1.34 & 1.09 & 1.65 & \\
\hline & 1.01 & 0.70 & 1.46 & \\
\hline Sex & & & & 0.0001 \\
\hline \multirow{2}{*}{$\begin{array}{l}\text { Male } \\
\text { Female }\end{array}$} & Ref & & & \\
\hline & 1.26 & 1.12 & 1.42 & \\
\hline Education & & & & $<0.0001$ \\
\hline \multirow{4}{*}{$\begin{array}{l}\text { Less than secondary school graduate } \\
\text { Secondary school graduate } \\
\text { Some post-secondary education } \\
\text { Post-secondary certificate }\end{array}$} & Ref & & & \\
\hline & 0.83 & 0.68 & 1.02 & \\
\hline & 1.06 & 0.76 & 1.47 & \\
\hline & 0.47 & 0.39 & 0.57 & \\
\hline Alcohol frequency & & & & 0.2776 \\
\hline \multirow{4}{*}{$\begin{array}{l}\text { Less than once a month } \\
\text { More than once a month but not weekly } \\
\text { More than once a week but not daily } \\
\text { Daily }\end{array}$} & Ref & & & \\
\hline & 0.93 & 0.78 & 1.11 & \\
\hline & 1.07 & 0.91 & 1.25 & \\
\hline & 0.97 & 0.80 & 1.18 & \\
\hline Type of smoker & & & & 0.1378 \\
\hline \multirow{3}{*}{$\begin{array}{l}\text { Never } \\
\text { Daily } \\
\text { Occasionally }\end{array}$} & Ref & & & \\
\hline & 1.19 & 1.00 & 1.42 & \\
\hline & 0.97 & 0.73 & 1.30 & \\
\hline \multicolumn{5}{|l|}{ Age smoked first whole cigarette } \\
\hline & 1.10 & 1.08 & 1.11 & $<0.0001$ \\
\hline Ethnicity type of smoker & & & & 0.0461 \\
\hline \multirow{11}{*}{$\begin{array}{l}\text { Caucasian immigrant - non-smoker } \\
\text { Asian immigrant - daily smoker } \\
\text { Asian immigrant - occasional smoker } \\
\text { Black immigrant - daily smoker } \\
\text { Black immigrant - occasional smoker } \\
\text { Latino immigrant - daily smoker } \\
\text { Latino immigrant - occasional smoker } \\
\text { Arab immigrant - daily smoker } \\
\text { Arab immigrant - occasional smoker } \\
\text { Other immigrant - daily smoker } \\
\text { Other immigrant - occasional smoker }\end{array}$} & Ref & & & \\
\hline & 0.81 & 0.52 & 1.25 & \\
\hline & 1.30 & 0.77 & 2.19 & \\
\hline & 1.87 & 0.81 & 4.29 & \\
\hline & 2.44 & 0.81 & 7.34 & \\
\hline & 0.56 & 0.20 & 1.57 & \\
\hline & 3.85 & 1.46 & 10.14 & \\
\hline & 0.59 & 0.23 & 1.51 & \\
\hline & 0.33 & 0.06 & 1.75 & \\
\hline & 1.39 & 0.52 & 3.73 & \\
\hline & 2.26 & 0.56 & 9.11 & \\
\hline Random effects & Effect estimate & LL 95\% Cl & UL 95\% CI & \\
\hline \multirow{3}{*}{$\begin{array}{l}\text { Level } 3 \text { - Province of residence } \\
\text { Level } 2 \text { - Health region of residence } \\
\text { Level I - Individual level }\end{array}$} & 0.03 & 0.01 & 0.12 & \\
\hline & 0.05 & 0.02 & 0.11 & \\
\hline & 1.00 & & & \\
\hline \multicolumn{5}{|l|}{ Intraclass correlation } \\
\hline \multirow{2}{*}{$\begin{array}{l}\text { Same province - same health region } \\
\text { Same province - different health region }\end{array}$} & $2.4 \%$ & & & \\
\hline & $0.9 \%$ & & & \\
\hline
\end{tabular}

Notes: LL $95 \% \mathrm{Cl}$, lower limit of the $95 \% \mathrm{Cl}$; $\mathrm{UL} 95 \% \mathrm{Cl}$, upper limit of the $95 \% \mathrm{Cl}$.

Abbreviation: OR, odds ratio.

between Caucasian immigrants and the native-born population in Canada may be suggestive of strong underlying sociocultural similarities and ties between the two groups.
On an average, the majority of immigrants started smoking 3 years later than the native-born Canadians. This finding may be best understood by the social learning theory, ${ }^{24}$ which 
Table 4 Marginal effects

\begin{tabular}{|l|l|l|l|}
\hline \multirow{2}{*}{$\begin{array}{l}\text { Ethnicity of } \\
\text { immigrants to } \\
\text { Canada }\end{array}$} & \multicolumn{3}{|l|}{$\begin{array}{l}\text { Odds of smoking initiation after } \\
\text { migration to Canada }\end{array}$} \\
\cline { 2 - 4 } & $\begin{array}{l}\text { Never } \\
\text { smokers }\end{array}$ & $\begin{array}{l}\text { Occasional } \\
\text { smokers }\end{array}$ & $\begin{array}{l}\text { Daily } \\
\text { smokers }\end{array}$ \\
\hline Caucasian immigrants & $0.89^{\mathrm{a}}$ & $2.49^{\mathrm{b}}$ & $1.29^{\mathrm{a}}$ \\
\hline Asian immigrants & $0.65^{\mathrm{a}}$ & $1.36^{\mathrm{a}}$ & $0.62^{\mathrm{a}}$ \\
\hline Black immigrants & $0.59^{\mathrm{a}}$ & $4.82^{\mathrm{b}}$ & $1.09^{\mathrm{a}}$ \\
\hline Latino immigrants & $0.48^{\mathrm{c}}$ & $4.34^{\mathrm{b}}$ & $0.29^{\mathrm{a}}$ \\
\hline Arab immigrants & $2.39^{\mathrm{a}}$ & $0.83^{\mathrm{b}}$ & $0.63^{\mathrm{b}}$ \\
\hline Other immigrants & $0.59^{\mathrm{c}}$ & $11.03^{\mathrm{b}}$ & $1.20^{\mathrm{a}}$ \\
\hline
\end{tabular}

Notes: Odds, probability of event/probability of non-event (event here is smoking after migration to Canada). Odds $>$ I suggests an increased probability of smoking after migration to Canada. Odds $<\mid$ suggests an increased probability of smoking before migration to Canada. ${ }^{a}$ Statistically significant with $P<0.01$. 'Statistically cannot ascertain if smoking was likely to have preceded migration or followed migration. 'Statistically significant with $P<0.05$.

stresses the role of exposure to pre-smoking socio-cultural influences such as parental and peer attitudes toward cigarette use and/or the differential vulnerability to those influences as contributors to ethnic differences in smoking. ${ }^{10}$ It is reported that immigrant parents may be more strict and vigilant in monitoring their children's cigarette smoking behaviors, when compared to Canadian parents. ${ }^{25,26}$ However, research has shown that for immigrant youth, native-born peers play an important role and are more likely to influence their smoking behaviors than their parents. ${ }^{27-30}$

Immigrants who were younger, single, Caucasian, females with high income and some post-secondary education were significantly more likely to start smoking postmigration to Canada. The social learning theory suggests that the active interaction of young immigrants with their Canadian peers may help influence their smoking initiation and behaviour. ${ }^{15}$ Griffin et al identified the smoking behavior of friends as a major predictor of smoking initiation among ethnic minority youths. ${ }^{31}$ Studies have also shown that young females are more likely to start smoking, when compared to young men of the same age. ${ }^{32}$ One possible explanation may be that young women mature earlier than young men and are quicker to adopt adult habits in Canada. Our study also found a direct correlation between higher income and education levels and the likelihood of smoking initiation. This may be attributed to issues of accessibility, affordability, and social desirability.

Self-perceived health and life stress were also significant predictors of smoking initiation post-migration to Canada. Paradoxically, young immigrants who perceived to be in very good or excellent health had an increased likelihood to start smoking. It has been reported that young people have self-exempting beliefs that cause them to underestimate the likelihood of addiction, health risks, and consequences of cigarette smoking. ${ }^{33,34}$ Studies have also shown that new immigrants experience increased levels of stress due to issues related to resettlement, school, employment, and absence of established social networks. ${ }^{35,36}$ Thus, the initiation of smoking might be used as a coping mechanism to help them reduce the various stresses and challenges associated with their migration to a new country. ${ }^{37}$

\section{Strengths and limitations}

Our study had a few limitations. First, the analyses were based on self-reported data. Second, due to the cross-sectional nature of the survey, we were unable to draw causal inferences between the variables explored and the outcomes of interest. Third, it used telephone surveys, which may lack representativeness, as households without landline telephones were not included. Finally, this study did not examine the genotyping or the duration of smoking and its molecular impact (epigenetic changes). Despite its aforementioned limitations, this study also had a number of significant strengths. It used a large, representative, nation-wide, multi-ethnic sample and specifically looked to identify ethnic differences in the preferences of cigarette smoking and smoking initiation among Canadian immigrants.

\section{Conclusion}

The results of our study suggest that Caucasian female immigrants in Canada initiated smoking at a younger age and smoked more cigarettes than any other immigrant group or native-born Canadians. This is a particularly interesting finding as Caucasian female immigrants may not be considered a vulnerable or at-risk population. To be effective, tobacco strategies specifically tailored for this overlooked population would require increased awareness, culturally appropriate initiatives, and gender-specific interventions.

\section{Ethics statement}

The CCHS was implemented and conducted with the cooperation, support, and funding of Statistics Canada. The opinions expressed in this paper do not represent the views of Statistics Canada. Please note that the publishing of analysis and results from research studies using any of the data products in research communications such as scholarly papers and journals is permitted by Statistics Canada. This study is exempt from ethics approval because it relies on the use of Statistics Canada public files and secondary analysis of anonymous data (Tri-Council Policy Statement, articles 2.2 and 2.4, respectively). Participation in this survey was voluntary. 


\section{Availability of data and materials}

All data and materials are stored in the Research Data Centre, University of Saskatchewan, Canada.

\section{Acknowledgments}

We gratefully acknowledge the Research Data Center, University of Saskatchewan for kindly granting us access to the micro-files via an agreement with Statistics Canada. This research was supported in part by an internal grant from the School of Public Health, University of Saskatchewan.

\section{Author contributions}

$\mathrm{JM}, \mathrm{YB}, \mathrm{KF}$, and $\mathrm{CN}$ were involved in the study conception and design. JM, KF, and $\mathrm{CN}$ were responsible for the data analysis. All authors contributed to the discussion; interpreted the findings; helped write, reviewed/edited the manuscript for intellectual content; and read and approved the final manuscript.

\section{Disclosure}

The authors report no conflicts of interest in this work.

\section{References}

1. U.S. Department of Health and Human Services. Tobacco use among US racial/ethnic minority groups: African Americans, American Indians and Alaska Natives, Asian Americans and Pacific Islanders, Hispanics. A report of the Surgeon General, 1998. Atlanta, GA: Health and Human Services, Centers for Disease Control and Prevention, National Center for Chronic Disease Prevention and Health Promotion, Office on Smoking and Health, 1998. Available from: https://www.cdc.gov/tobacco/ data_statistics/sgr/1998/complete_report/pdfs/complete_report.pdf. Accessed December 11, 2017.

2. Baliunas D, Patra J, Rehm J, Popova S, Kaiserman M, Taylor B. Smoking-attributable mortality and expected years of life lost in Canada 2002: conclusions for prevention and policy. Chronic Dis Can. 2007;27(4):154-162.

3. Dobrescu A, Bhandari A, Sutherland G, Dinh T. The Costs of Tobacco Use in Canada, 2012. Ottawa: The Conference Board of Canada, 2017. Available from: https://www.canada.ca/content/dam/hc-sc/documents/ services/publications/healthy-living/costs-tobacco-use-canada-2012/Costsof-Tobacco-Use-in-Canada-2012-eng.pdf. Accessed January 29, 2018.

4. Statistics Canada. Smoking 2014-2015. Available from: http://www.statcan.gc.ca/pub/82-625-x/2015001/article/14190-eng.htm\#n1. Accessed December 10, 2017.

5. Newbold KB, Neligan D. Disaggregating Canadian immigrant smoking behaviour by country of birth. Soc Sci Med. 2012;75(6):997-1005.

6. Perez CE. Health status and health behaviour among immigrants. Health Rep. 2002;13:1-13.

7. Statistics Canada. Immigration and ethno-cultural diversity in Canada, National Household Survey 2011. Available from: http://www12. statcan.gc.ca/nhs-enm/2011/as-sa/99-010-x/99-010-x2011001-eng.pdf. Accessed December 7, 2017.

8. Malenfant ÉC, Lebel A, Martel L. Projections of the diversity of the Canadian population, 2006-2031. Statistics Canada, Demography Division, 2010. Available from: https://www.statcan.gc.ca/pub/91-551-x/ 91-551-x2010001-eng.htm. Accessed January 11, 2018.

9. Centers for Disease Control and Prevention. Health disparities experienced by racial/ethnic minority populations. MMWR Morb Mortal Wkly Rep. 2004;53(33):755-782.
10. Ellickson PL, Perlman M, Klein DJ. Explaining racial/ethnic differences in smoking during the transition to adulthood. Addict Behav. 2003;28(5): 915-931.

11. Holowaty P, Feldman L, Harvey B, Shortt L. Cigarette smoking in multicultural, urban high school students. J Adolesc Health. 2000; 27(4):281-288.

12. Stoll K. Correlates and predictors of tobacco use among immigrant and refugee youth in a Western Canadian city. J Immigr Minor Health. 2008; 10(6):567-574.

13. Johnson RA, Hoffmann JP. Adolescent cigarette smoking in U.S. racial/ ethnic subgroups: findings from the National Education Longitudinal Study. J Health Soc Behav. 2000;41(4):392-407.

14. Lawrence D, Graber JE, Mills SL, Meissner HI, Warnecke R. Smoking cessation interventions in U.S. racial/ethnic minority populations: an assessment of the literature. Prev Med. 2003;36(2):204-216.

15. Asbridge M, Tanner J, Wortley S. Ethno-specific patterns of adolescent tobacco use and the mediating role of acculturation, peer smoking, and sibling smoking. Addiction. 2005;100(9):1340-1351.

16. Au JG, Donaldson SI. Social influences as explanations for substance use differences among Asian-American and European-American adolescents. J Psychoactive Drugs. 2000;32(1):15-23.

17. Unger JB, Palmer PH, Dent CW, Rohrbach LA, Johnson CA. Ethnic differences in adolescent smoking prevalence in California: are multiethnic youth at higher risk? Tob Control. 2000;9(Suppl 2):ii9-ii14.

18. Gx M, Lan Y, Edwards RL, Shive SE, Chau T. Evaluation of a culturally tailored smoking prevention program for Asian American youth. J Alcohol Drug Educ. 2004;48(3):17-39.

19. Statistics Canada. Surveys and statistical programs - Canadian Community Health Survey - Annual Component (CCHS). 2014. Available from: http://www23.statcan.gc.ca/imdb/p2SV.pl? Function= getSurvey\&Id=164081. Accessed January 14, 2018.

20. Hosmer DW, Lemeshow S, Sturdivant RX. Applied Logistic Regression. 3rd ed. Hoboken, NJ: John Wiley and Sons, Inc; 2013.

21. Bursac Z, Gauss CH, Williams DK, Hosmer DW. Purposeful selection of variables in logistic regression. Source Code Biol Med. 2008;3(1):17.

22. Dohoo IR, Martin SW, Stryhn H. Methods in Epidemiologic Research. Charlottetown, P.E.I: VER, Inc; 2012.

23. Snijders TA. Multilevel Analysis. Springer Berlin Heidelberg: International Encyclopedia of Statistical Science; 2011:879-882.

24. Bandura A. Self-efficacy: toward a unifying theory of behavioral change. Psychol Rev. 1977;84(2):191-215.

25. Wallace JM. Explaining race differences in adolescent and young adult drug use: the role of racialized social systems. Drugs Soc. 1998;14(1-2): 21-36.

26. Griesler PC, Kandel DB, Davies M. Ethnic differences in predictors of initiation and persistence of adolescent cigarette smoking in the National Longitudinal Survey of Youth. Nicotine Tob Res. 2002;4(1):79-93.

27. Ellickson PL, Orlando M, Tucker JS, Klein DJ. From adolescence to young adulthood: racial/ethnic disparities in smoking. Am J Public Health. 2004;94(2):293-299.

28. Bird Y, Staines-Orozco H, Moraros J. Adolescents' smoking experiences, family structure, parental smoking and socio-economic status in Ciudad Juárez, Mexico. Int J Equity Health. 2016;15:29.

29. Flay BR, Hu FB, Siddiqui O, et al. Differential influence of parental smoking and friends' smoking on adolescent initiation and escalation of smoking. J Health Soc Behav. 1994;35(3):248-265.

30. Landrine H, Richardson JL, Klonoff EA, Flay B. Cultural diversity in the predictors of adolescent cigarette smoking: the relative influence of peers. J Behav Med. 1994;17(3):331-346.

31. Griffin KW, Botvin GJ, Scheier LM, Doyle MM, Williams C. Common predictors of cigarette smoking, alcohol use, aggression, and delinquency among inner-city minority youth. Addict Behav. 2003;28(6):1141-1148.

32. Grogan S, Conner M, Fry G, Gough B, Higgins A. Gender differences in smoking: A longitudinal study of beliefs predicting smoking in 11-15 year olds. Psychol Health. 2009;24(3):301-316.

33. Mantler T. A systematic review of smoking Youths' perceptions of addiction and health risks associated with smoking: Utilizing the framework of the health belief model. Addict Res Theory. 2013;21(4):306-317. 
34. Bird Y, Moraros J, Olsen LK, Forster-Cox S, Staines-Orozco H, Buckingham RW. Smoking practices, risk perception of smoking, and environmental tobacco smoke exposure among 6th-grade students in Ciudad Juárez, Mexico. Nicotine Tob Res. 2007;9(2):195-203.

35. Ali J. Mental Health of Canada's Immigrants. Health Rep. 2002;13: 101-113.
36. Beiser M. The health of immigrants and refugees in Canada. Can $J$ Public Health. 2005;96(Suppl 2):S30-S44.

37. Crutchfield RD, Gove WR. Determinants of drug use: a test of the coping hypothesis. Soc Sci Med. 1984;18(6):503-509.

Patient Preference and Adherence

\section{Publish your work in this journal}

Patient Preference and Adherence is an international, peer-reviewed, open access journal that focuses on the growing importance of patient preference and adherence throughout the therapeutic continuum. Patient satisfaction, acceptability, quality of life, compliance, persistence and their role in developing new therapeutic modalities and compounds to optimize clinical outcomes for existing disease states are major areas of interest for the journal. This journal has been accepted for indexing on PubMed Central. The manuscript management system is completely online and includes a very quick and fair peer-review system, which is all easy to use. Visit http://www. dovepress.com/testimonials.php to read real quotes from published authors.

\footnotetext{
Submit your manuscript here: http://www.dovepress.com/patient-preference-and-adherence-journal
} 